\title{
Insider Mediation in Peace Processes: An Untapped Resource?
}

\author{
Kristina Roepstorff and Anna Bernhard*
}

\begin{abstract}
Mediation is considered an effective and peaceful tool for the resolution of conflicts and has become an important instrument in international peacemaking. Interest in mediation has surged in recent years both at the international and regional level. In line with the discussions of local ownership in peacebuilding literature and practice, there is also an increased call for including local 'insider mediators' in peace processes. So far, scholars have paid little attention to the role of insider mediators in peacemaking. To gain a better understanding of their actual and potential role in peace processes, a systematic analysis of the phenomenon of insider mediation is therefore indispensible.
\end{abstract}

Keywords: Mediation, peace process, peacemaking, insider mediation, conflict transformation Mediation, Friedensprozess, Friedensschaffung, Insider-Mediation, Konflikttransformation

\section{International Peace Mediation}

$\mathrm{M}$ ediation is widely used to handle disputes. Most generally, mediation can be defined as a process in which a third party intervenes in a conflict to bring about a peaceful settlement between the disputants and contribute to a successive transformation of the conflict. As extensively documented and analysed by anthropologists and sociologists, mediation has been applied for centuries in different cultural contexts. In particular, insights from the field of legal anthropology, with its primary interest in the social order of societies and the use of formal and informal mechanisms for enforcing laws and handling disputes, reveal the widespread use of mediation in cross-cultural perspective.

At the international level, the Charter of the United Nations from 1945 lists in Article 33 mediation alongside negotiation, conciliation and arbitration as a peaceful means to settle disputes between member states. Since the end of the Cold War, the international community of states has increasingly intervened in intrastate conflicts and civil wars and, as a result, international mediation efforts have extended to conflicts at the intra-state level. Today, mediation presents the most common, and often most effective, form of peaceful third-party intervention both in interstate and intrastate conflicts and has been successfully applied to initiate peace negotiations and broker peace agreements in violent conflicts around the world (Bercovitch and Gartner 2009).

Seen as an effective, peaceful, and democratic peacemaking tool, recent years have shown a renewed interest in the use of mediation in peace processes. Both the United Nations (UN) and the European Union (EU) have been called upon to strengthen their mediation capacities with the objective of becoming more actively involved in international peace mediation, facilitation and dialogue processes (Tamminen 2012: 10). On September 27, 2012 the UN launched a new 'Guidance for Effective Mediation' as part of a broader report on conflict mediation that has been issued at the request of the General Assembly. The European Council in 2009

Dr. Kristina Roepstorff, Visiting Fellow, German Institute for International and Security Affairs/Stiftung Wissenschaft und Politik, Berlin; Anna Bernhard, Project Officer, Berghof Foundation, Berlin. adopted the 'Concept on Strengthening EU Mediation and Dialogue Capacities' with the objective of becoming more actively involved in mediation, facilitation and dialogue processes. This objective was reaffirmed in the 'European Council Conclusions on Conflict Prevention' in 2011 (ibid). In 2010, the Finnish and Swedish Foreign Ministers proposed the creation of a European Institute of Peace (EIP) to support peace mediation worldwide. Similarly, other regional organisations like the Association of Southeast Asian Nations (ASEAN) and the African Union (AU) continue to work to strengthen their peace mediation support capacities (Wolff and Yakinthou 2011).

While focusing on efforts to increase mediation capacities at the global and regional level, the importance to engage with local actors involved in peace mediation is mentioned in an increasing number of the international and regional organisations' guidelines and strategy papers. The UN Guidance for Effective Mediation (2012a: 9), for instance, stresses the importance to engage with local and community-based actors or organisations to encourage the use of mediation, to liaise with and ensure support for local peacemakers and, wherever appropriate, use indigenous forms of conflict management and dispute resolution (ibid: 15). The EU Concept on Strengthening Mediation Capacities states that "by supporting local mechanisms for mediation and dialogue, [these] EU activities on the ground help transform relationships between conflict parties, leading to genuine and sustainable solutions in conflict-prone environments" (2009: 5). Furthermore, it acknowledges the expertise of national, local and civil society actors as a resource already available and that should be made best use of (ibid: 11). In recognising their significant role in conflict prevention and early-warning, the Economic Community of West African States (ECOWAS) and the Intergovernmental Authority on Development (IGAD) already work with a network of local monitors and mediators (Hislaire et al. 2011). An explicit reference to the role of so-called insider mediators is made in a paper published by the Crisis Management Initiative (CMI) as a follow-up to the 'ASEAN-EU High-Level Expert Workshop on Preventive Diplomacy and International Peace Mediation' that was held in October 2011. The reference, worth citing in full length, states that 
"There is also a broad based understanding that "peace mediation' automatically means a third party support being provided by persons and institutions outside of the affected country. A closer look at the reality of most peace processes reveals though that there crucial roles with respect to conflict transformation are also played by 'insiders', i.e. persons who are perceived as belonging ethnically, religiously or in other respect to one of the conflict parties, but who try to deescalate the conflict, build bridges, engage in peace advocacy. Sometimes they are also called '(semi-)partial insiders'. Many of them belong to the important group of insider peacebuilders being active on the 'Track 3' and 'Track 2' levels. But some of them also operate on higher levels of engagement, i.e. 'Track 1.5 ' and 'Track 1 ' and they often build alliances with different allegiances to the parties to support conflict transformation in a discreet manner. A closer look at mediation in the ASEAN region reveals that in most conflict cases there are persons with experience, commitment and a good rapport with the conflicting parties who play these roles. Because international intervention is a very sensitive issue for some ASEAN Member States, it is highly advisable to explore their contributions and potential more in detail and also to explore, how their support can be made more effective. In several cases it also advisable to look for creative ways to combine mediation efforts from outside of the country with those from inside."

(Cristescu et al. 2012: 19)

In a similar manner, non-governmental organisations such as the Berghof Foundation and swisspeace (Mason 2009), as well as the PeaceNexus Foundation (Hislaire et al. 2011) have highlighted the important contributions of insider mediators in peace processes.

As the references suggest, international interest in insider mediation is growing. Two main factors may explain this. First, the awareness among international actors of the importance to include local actors in peace processes both to enhance the legitimacy of international interventions and to allow for more sustainable peace processes has brought about a reconsideration of common peace intervention practices. As a result, international norms such as local ownership, inclusiveness, and capacity-building have become commonplace in peacebuilding scholarship and practice. Second, the realisation that peace processes are initiated and accompanied by mediation efforts from local insider mediators who facilitate, complement and support the work of official outsider mediators (Giessmann and Wils 2011: 188) has led to the realisation that although international outsider mediators play a crucial role in the settlement of conflicts, insider mediators play a critical role in linking external mediation efforts with local conflict transformation processes (Gourlay and Ropers 2012).

Proponents of the inclusion of insider mediators into peace processes point towards insider mediators' advantage of an indepth knowledge of the conflict context, its dynamics, as well as the involved parties and their interests. They are familiar with the cultural norms, the language and ways of communication, as well as the social structures, power configurations and hierarchies exigent in the conflict context (UN, 2012b: 6). This knowledge allows them to "demonstrate a nuanced sensitivity in their contribution to find solutions to conflicts that are owned and valued by the parties themselves" (ibid). This closeness to the conflict and the conflict parties is regarded an asset rather than an obstacle for mediating in the conflict something that stands in sharp contrast to the widespread ideal of the impartial and distanced mediator in Western professional mediation trainings. The interest in insider mediators thus raises at least two important questions. The first regards the distinction between insiders and outsiders. While the interest in the role of local actors, or insider mediators, in peace processes is growing, it is unclear who should be considered an insider or outsider in a given context. The second question concerns the extent to which Western ideals of mediation professionalism clash with local ideas and practices of mediation. And, as an extension of this question, how outsiders and insiders may work together and complement each other in their quest to achieve sustainable peace.

\section{The Insider-Outsider Dichotomy}

While there is a growing interest in insider mediation, it is far from clear who accounts for an 'insider' or an 'outsider' in a given conflict. Indeed, insider and outsider mediation are relative terms (Mason 2009: 4) and ambiguously used by scholars and parties to the conflict alike. For instance Elgström et al. (2003) use the notion of insider mediator in reference to regional organisations, rather than local civil society actors. A similar distinction between insiders and outsiders is presented by Gilbert Khadiagala (2007) in his book Meddlers or Mediators: African Interveners in Civil Conflicts in Eastern Africa. While not using the term 'insider mediator' explicitly, he distinguishes African mediators from external mediators. From this point of view, the regional organisation - in this case the AU - is more an insider to the conflicts on the continent than the UN. A national mediator, on the other hand, is more an insider than a representative from the regional organisation, and so forth.

The difficulties to differentiate between 'insider' and 'outsider' bares resemblance to the discussion concerning the categorisation of 'local', 'national' and 'international' widely used in the peacebuilding literature. The label 'international' is commonly used in reference to a broad set of actors, including foreign governments, international governmental organisations (IGOs), international and trans-national nongovernmental organisations (NGOs), foreign NGOs, but also researchers from academic institutions and think-tanks. All of these compose what is often referred to as the 'international community', which is, however, far from unified. As with international actors, the term 'local' subsumes a broad set of actors who actively work in the conflict area, including activists, local NGOs, local government representatives, church groups, and local staff of outside or foreign NGOs and agencies (Anderson 2003: 36). The term 'local' is, however, misleading in the sense that it does not refer to a geographic area but rather to a person's or organisation's closeness and vulnerability to the conflict (ibid), or the impact of a peacebuilding initiative (Reich 2006: 21). In practice, 'local' 
actors who are directly affected by and have a stake in the conflict and the impact of the conflict resolution initiatives are therefore often referred to as 'insiders' to the conflict and the conflict transformation initiative. According to Anderson (2003: 36), insiders either live in the conflict area and are thus vulnerable to the conflict, or experience the conflict from a distance and must "live with its consequences personally".

While the insiders cannot escape the conflict setting and its consequences, the outsiders - ranging from foreign staff of organisations, members of the Diaspora, and co-nationals from regions of a country not directly affected by the violence - have the opportunity to choose whether and to what extent they want to be involved in the conflict and its resolution process. This, however, has consequences on how they are perceived by the parties to the conflict. Thus, the insiderness and outsiderness are ascribed both on the basis of how actors are perceived by others and how they perceive themselves. This happens at different levels. First, an actor might subjectively perceive himself or herself as insider, while being perceived as an outsider by the parties to a conflict. On a different level, a researcher may use etic ascriptions of 'insiderness' and 'outsiderness' without these categories corresponding with emic categorisations. To further complicate matters, perceptions can change over time, depending on the context, position and perspective. Moreover, some actors can simultaneously hold insider and outsider positions. For example, national governments sometimes take up the role of a mediator between international and local actors. By doing so, they might also represent different and deviant positions when talking to international actors and to local actors (Bernhard 2013: 9).

As many other labels used in social sciences, the distinctions between 'local' and 'international', 'insiders' and 'outsiders' present an oversimplification that does not match the complexity of ground realities. As a consequence, one needs to define the meaning of the local and the external, the insider and the outsider, in each case, acknowledging that the labels themselves are not fixed but fluid categories and part of a process of hybridisation (Jacobsen and Lidén 2013: 29; Mac Ginty 2010: 397). Defining an actor is thus only possible in grades of insiderness or outsiderness by referring to one as being more or less of an insider or outsider compared to others (Anderson 2003: 36). Notwithstanding the relativity of the categories, the identification of basic characteristics may allow us to differentiate between insider and outsider mediation. Besides the mediator's closeness to the conflict and the conflict parties, insider mediation is often characterised by what could be defined as everyday mediation practice - and which differs in terms of techniques and strategies promoted by the Western model of mediation professionalism, as the next section shows.

\section{The Phenomenon of Insider Mediation}

\subsection{Different Models of Mediation}

Like other spheres of life, peacebuilding has experienced a technocratic turn in recent decades (Mac Ginty et al. 2012). Formal processes and standardised bureaucratic and technocratic means and norms are applied in peacebuilding and peacemaking (ibid: 37ff). Such a technocratic approach is believed to be value-free and neutral since decisions would be based on "objective criteria" (ibid). In the same line of thinking, and most important in the Western model of mediation professionalism, the mediator is supposed to be impartial to the conflict parties and an outsider to the conflict context (Wehr and Lederach 1991: 86). The distance between the mediator and the conflict parties is strongly emphasised and regarded as the source of the mediator's authority and professionalism. This emphasis emanates from the assumption that if this distance is not kept, the mediator's partiality, connectedness to the conflict parties, expectations for rewards and investments in outcomes of the mediation process would negatively affect and manipulate the outcome of the mediation process (ibid; Moore 2003: 15-16).

International peace mediation is predominantly shaped by this Western ideal of professionalism that has its origin in the ADR (Alternative Dispute Resolution) movement and which started in the 1970s in North-America (Roberts and Palmer 2005). Successfully promoting mediation as an alternative to court for the settlement of disputes, it can be argued that the ADR movement prompted a technocratic approach to mediation. An ensuing model of Western mediation professionalism is based on an understanding of mediation as a formal process initiated by an experienced third-party professional (Merry 1987: 1; Moore 2003: 15-16) and used in the training of mediators around the world. Thus, although many Western countries have a history of diverse informal models of mediation still being applied in local everyday situations, a formal model of mediation has established itself and become widely accepted.

This formal model of mediation with its specific ideas about the proper process of mediation, the qualifications and role of the mediator as a professional and distant facilitator, and the relationship of the mediator to the parties to the conflict (Golbert 2009: 83) stands in contrast to what we know from anthropological and sociological studies of dispute settlement in different societies. These findings allow us to rethink some of the assumptions originating from the West about what makes mediation work in different cultural contexts (ibid). As early as 1908, the German sociologist Georg Simmel identified the omnipresence of the mediator across all cultures and distinguished between mediators as disinterested neutral third parties (outsider mediators) on the one hand, and mediators actively and equally concerned with the interests of all parties, such as family members and community elders (insider mediators) on the other hand (Simmel 1950). Likewise, Augsburger (1992) finds that mediation is the most frequently used process of dispute settlement in traditional societies. His and other anthropological studies call into question the Western formal model of mediation that suggests the ideal mediator to be impartial, unbiased, and unconnected to the conflict and parties to the conflict (Golbert 2009: 87). In his study on the dispute settlement process in the Chamar community in North-India in the 1950s, the British anthropologist Bernard S. Cohn found that the leaders of the disputants' community units take the role of mediators 
in the settlement process. By social definition, the leaders' legitimacy is based in "his ability to function not only as a leader of one unit but to lead in the next larger unit" and to "bridge the gap" between these units "by balancing between advocate of the rights of this immediate followers and the demands of the wider social group" (Cohn 1959: 85). These mediation processes are characterised by public attention and commenting while the mediator's task is to "sense" and "direct" the "public opinion" during the process (ibid).

Similarly, findings from peace and conflict research have called into question the emphasis on neutrality and impartiality common in Western mediation trainings (Wehr and Lederach 1991; Elgström et al. 2003; Golbert 2009). In this regard, the distinction between processual, outcome and relational partiality as suggested by Elgström et al. (2003: 15) is particularly useful. Whereas processual partiality refers to the mediator's favouritism of one party during the mediation process (by e.g. giving them more time to express their viewpoint), and outcome partiality refers to his/her preference of one party's idea of settlement, relational partiality refers to a mediator's closeness to the conflict parties. It is argued that the insider mediators' partiality is relational rather than processual or outcome-oriented (Elgström et al. 2003: 15; Mason 2009: 5; UN 2012a: 6).

As Lee and Hwee Hwee (2009) claim for Asian societies, the mediator's 'connectedness' to the conflict parties is more treasured than a neutral relationship to them. Depending on the level and nature of the conflict, the mediators can be relatives, anybody the disputants have built up a relationship with, someone who is highly regarded in the community, or in the field where the conflict takes place (e.g. certain business branch). It is the connectedness or commonalities with the disputants that makes them trustworthy mediators. This is based on an understanding of trust as a "subjective element of intent" with a "strong [...] relational orientation" (ibid: 74). In this understanding, trust means that the parties can rely on the mediator's benign intention and benevolence towards all involved parties, and that the mediator will not take advantage of a party's vulnerability created by cooperation in the mediation process (Billings-Yun 2009: 149-150). This understanding of trust is different from the one prevailing in the West, where trust has a more objective connotation and a person gains generalised social trust in someone due to his/her educational background, experience, and achievements (ibid). While in Western professional mediation trust is centred on the mutual perception of unreliable behaviour of the disputing parties, a neutral mediator who has no connections to the conflicting parties is necessary, in order to facilitate non-judgemental interaction between them so that trust can be rebuilt during the mediation process (ibid). In societies where trust is relationally oriented, the mediator is not a detached facilitator but a party to the process of mediation and therefore needs to be trustworthy to all parties involved. He/she is expected to actively seek a solution to the dispute and ideally has positive intentions. In order to be accepted, the mediator has to first prove his/her benevolence to the parties, which usually happens in a preparatory phase of the mediation processes (ibid: 151152). Thereby, it is important that the grade of connectedness to each conflict party is as equal as possible, or, in Cobb and Rifkin's words "equidistant" (1991). If a mediator is more closely connected to one party, the other might not accept him/her as mediator and the mediation process is likely to fail (Lee and Hwee Hwee 2009: 75). In the case where no equally connected mediator can be found, co-mediators or multiple mediators can be an accepted solution (ibid).

In sum, these studies of mediation in contexts outside of Europe and the US reveal that neutrality and impartiality are not necessary preconditions for a mediation process to be successful. On the contrary, these characteristics can have inhibiting effects on the conflict parties' openness to talk and agree on a compromise (Billings-Yun 2009: 155). Accordingly, local mediators from within the conflict context being connected with all conflict parties may be more successful in mediating a conflict than their outsider counterparts (ibid). By being directly affected by the conflict, they are perceived as being more dedicated to the mediation outcomes. Following from these findings, insider mediation is characterised by the mediator's relational partiality and geographical and cultural closeness to the conflict; his/her legitimacy is derived from in-depth knowledge of the situation and rests in the trust and acceptance of the conflict parties. Thus, insider mediators stand in opposite to the ideal type of an outsider mediator who is characterised by his/her neutrality and 'distance' to the conflict and the parties. An outsider mediator might not have an in-depth knowledge of the conflict, but gains his legitimacy from professionalism (training as mediator) and his/her neutrality and impartiality.

A word of caution is required, however. It is important to acknowledge that insider mediators may be influenced by, or trained in, Western-style professional mediation. As Lee and Hwee Hwee (2009) discuss in reference to mediation in Singapore, but also in China, South Korea, Japan, Malaysia, Indonesia, Thailand, and the Philippines, traditional mediation methods may have been replaced by and combined with Western-style mediation techniques. They state that in these countries, preference has traditionally been given to insider mediators. The mediator has mostly been a person of "high standing in the community", known and trusted by the parties, and derived his/her authority from the disputants' respect for him/her, their faith in his/her integrity, wisdom, expertise and experience (2009: 10). In the traditional mediation methods, "moral persuasion" based on cultural and community values (e.g. virtue of forgiveness, compassion, respect and reason) played an important role. In these cases, the disputants were convinced to agree on a compromise for the sake of showing respect for or giving face to the mediator, to satisfy their community, to restore the relationships and social harmony (ibid). Nowadays, the mediation techniques have changed. Influenced by mediation models based in Western societies, the mediator is usually trained and certified, and acts under the official law. He/she takes up a rather facilitative role and avoids intervening into process- and substance-related issues or morality. Mediation is usually rights-based and judgedriven, while the judge discusses possible settlement options and respective consequences with the disputants (ibid: 11-13). What remained the same is the expectation of a mediator to 
be an authoritative figure who takes the lead of the mediation process (ibid: 73). Depending on the context and the dispute, an elderly community leader may be respected as an authority to mediate in a dispute among neighbours, while a judge with commercial law experience may be respected as an authority to mediate in a conflict between high-end corporations (ibid: 73).

The interaction of outsiders and insiders often result in compositions of exogenous and endogenous models. In reference to peace processes, Mac Ginty (2010) and Richmond (2009; 2010) have therefore pointed out the 'hybridity' of peacebuilding realities. However, as Mac Ginty argues in his book International Peacebuilding and Local Resistance: Hybrid Forms of Peace (2011: 2), the agency and diversity of local-level actors in peace processes is generally overlooked - as in the case of insider mediation and its contribution to peace processes. Apart from the above mentioned exceptions, the literature on international peace mediation mainly focuses on mediation as something that is 'done to' rather than 'done by' civil society members or local actors, as Porter and Every put it (2009: 44). As a result, and despite of a growing interest in insider mediation, little is known about their role in peace processes and the ways in which they complement external peace mediation efforts.

\subsection{The Role of Insider Mediators in Peace Processes}

Findings from anthropological and sociological research on dispute settlement in various societies, as well as findings from peace research suggest that in societies with a relational-oriented understanding of trust, it is more difficult for outsider mediators to be accepted as mediators. In a seminal work on peace processes in Central America, Lederach and Wehr (1991) develop the concept of the insider-partial mediator. They find that mediators were selected from the community on the basis of confianza (trust) and suggest broadening the concept of mediation to include the intervention of the insider-partial mediators in the transformation of conflicts. Moreover, as Lee and Hwee Hwee (2009: 74-75) find, in the Asian context mediators who are connected to the conflict parties can gain an 'insider rank', while neutrality towards the parties would downgrade them as members of an out-group or outsiders who are held off. The insiders are accepted as mediators to pave the way for the settlement, they enjoy easier access to information, and the disputants might be more open to accept mutual compromise, and even to give face to the mediators. Gourlay and Ropers (2012: 93 ff.) hold that their insiderness and partiality allow them to operate in situations where external actors do not have access or are not accepted; they can complement the role of outsiders by linking mediation from the high-level to the lower level processes; they are relevant for countries in transition or fragile contexts where there are no formal mediation structures; and they can play a crucial role in preventing and containing conflict. Findings from Nepal and other countries show that "in many conflict-affected countries the majority of domestic and land disputes are resolved through mediation efforts by local networks of individuals" (ibid: 97). Similar findings from the author's field research conducted in Assam, Northeast
India, in May and June 2012 support this. ${ }^{1}$ During clashes between ethnic groups in several parts of Assam in 1996 peace committees (shanti committees) were formed, which then mediated between the different ethnic groups. Among other things, they held meetings in IDP (internally displaced persons) camps. The peace committee consisted of members from both communities, including members of student organisations, women's organisations and other respected individuals like religious leaders. References to comparable committees in other parts of Northeast India were made in a number of interviews.

The literature that links mediation and peacebuilding provides some additional insights concerning the role and strategies of insider mediators in peace processes. Though not explicitly addressing the role of insider mediators as such, the literature addresses both informal and formal mediation processes and actors. As Bercovitch and Kadayifci (2002: 21) argue, mediation is an important aspect of peacebuilding. This view is shared by Lund (2001) and Paffenholz (2001) who place mediation within the broader framework of formal and informal peacebuilding activities. According to Porter and Every (2009:75) informal peacebuilders within civil society can make a substantial difference to disrupting political deadlocks and providing alternatives to on-going conflicts. Findings from this field of research suggest that whilst state-level mediators typically use a traditional diplomacy approach to mediation, civil society mediators such as international and local NGOs, research institutes, churches and individuals use a variety of mediation approaches and strategies (Paffenholz 2001: 75).

This is supported by the few reports published by nongovernmental organisations and that explicitly address insider mediation. Based on experiences of insider mediators in Nepal, Uganda, Mali, Philippines, Burundi, Kenya and Kyrgyzstan, Simon Mason concludes that insider mediators draw in multiple resources that are deeply embedded in their cultural context (2009: 16). Their insiderness and partiality also allows them to influence the conflict parties' behaviour "on a normative level" (ibid: 4). He further stresses the complimentary roles of insider and outsider mediators as well as the role insider mediators play in 'weak' states (ibid: 18). Furthermore, they are more flexible regarding methods, activities and time compared to official outsider mediators who usually are bound to a given mandate and timeframe (Giessmann and Wils 2011: 188).

Insider mediation may thus also help to overcome what Kyle Beardsley (2011: 4) has identified as an important dilemma of international peace mediation: the trade-off between the short-term and long-term effects of mediation. The argument is that third-party leverages exaggerate the trade-offs because their interfering involvement, while shaping the short-term incentives for peace, do not facilitate durable settlements. As a result, half of the mediated conflicts recur - leading to the conclusion that mediation makes peace less stable in the long run (ibid: 4). The long-term risks inherent in mediation can be even more pronounced in intrastate conflicts such as ethnopolitical conflicts. For instance, Gurses et al. (2008)

1 Roepstorff (2012); unpublished findings from research on conflict-induced displacement in Assam, North-East India, funded by the Canadian Government. 
argue that mediated agreements and great power mediation increase the fragility of peace after civil war. This stands in contrast to the various scholarly works that argue that leverage is crucial for successful mediation (Sisk 2009; Zartman and Touval 1996). Here, insider mediation may contribute to sustainable peacebuilding. Because insider mediators - unlike their outsider counterparts - stay and do not leave the conflict scene, they have a keen interest in the implementation and realisation of the peace agreement. Among other things, the legitimacy of insider mediators stems from the fact that in contrast to outsider mediators, insider mediators do not leave the scene after a peace agreement has been agreed but stay and support its realisation (Lederach and Wehr 1991: 94). In addition, their efforts at the local level may help to transform the conflict in the long run. Due to their in-depth knowledge of the conflict and the parties, insider mediators are more aware of the conflict parties' fragmentations and changing goals and strategies during war time and, thus, "can play an important role in facilitating the transformation of relations between the conflict parties" (Giessmann and Wils 2011: 189).

Insider mediators may, however, have very limited space to act. Comparing the activities of insider mediators in Kenya, Ghana, Burundi, the Democratic Republic of the Congo, Mozambique and Uganda Hislaire et al. (2011) find that apart from Kenya and Ghana, official peacebuilding efforts were largely driven from the outside. In the remaining cases, a reduced space for political dialogue and the threat of violent action are seen as the major obstacles for insider mediation. Thus, the extent to which insider or outsider mediators may play an active role in peace processes largely depends on the particular political context. In cases where outsiders may not have access to the conflict region and actors, insider mediators play a crucial role in the peace process. A case in point is Northeast India, were conflicts have not seen international intervention. ${ }^{2}$ An oppressive political climate may, on the other hand, limit the space for insider mediation and make the intervention of outsiders imperative. In either case, insiders and outsiders may work together and their activities can complement each other in the peace process.

\section{Conclusion}

Though insider mediation is increasingly acknowledged as an important resource for peacemaking and peacebuilding, there is a surprising lack of systematic scholarly research of insider mediators' roles in formal and informal peace processes. Insights from anthropological and sociological research on dispute settlement practices suggest that their characteristics, strategies and techniques may differ considerably from the mediation model as promoted in Western professional trainings. Findings from the few studies suggest that insider mediators may play an important role in peace processes. Yet, many aspects and fields of insider mediation still remain un-researched and vague, like the practical application of the dichotomy of insiders

2 Here representatives from the Central Government have mediated in the peace processes. Due to the political context and the (geographic, cultural and political) division between 'mainland' India and Northeast India, it can be argued that this presents a case for outsider mediation rather than insider mediation. and outsiders, the way insider mediators contribute to peace processes, and the interaction of insiders and outsiders in peace mediation. This lack of research and appreciation has a negative impact on insider mediators' work in peace mediation processes. Being regularly sidelined and ignored, insider mediators often work independently from outsider mediators, and the insiders' knowledge and resources thus often remain untapped. Their efforts are, however, generally not subsumed under a comprehensive peace strategy. This is surprising, especially in light of the local ownership debate and numerous studies and evaluations on international peacebuilding that show that international initiatives which include local perspectives, ideas and resources are more likely to be effective and sustainable than those which do not. This is also true of mediation - an awareness that is growing both in the research and practice of international peace mediation, but that requires further research for a better understanding of the existing and potential role of insider mediators in peace processes.

\section{Bibliography}

Anderson, M. and Olson L. (2003), Confronting War: Critical Lessons for Peace Practitioners. The Collaborative for Development Action, Cambridge.

Augsburger, D. (1992), Conflict Mediation across Cultures: Pathways and Patterns, Westminster: John Knox Press.

Beardsley, K. (2011), The Mediation Dilemma, New York: Cornell University Press.

Bercovitch, J. and Gartner, S. (eds.) (2009), International Conflict Mediation, Abingdon: Routledge.

Bercovitch, J. and Kadayifci, A. (2002), 'Exploring the relevance and contribution of mediation to peacebuilding', Peace and Conflict Studies, 9(2): 21-40.

Bernhard, A. (2013), Report on Theme C: The Dynamics of Relations between different Actors when Building Peace: The Role of Hybridity and Culture. CORE Project Deliverable D.4.3. Workpackage 4 - Thematic Analysis.

Billings-Yun, M. (2009), Trust in Mediation, in: Lee, Joel and Teh Hwee Hwee (eds.), An Asian Perspective on Mediation. Singapore: Academy Publishing.

Cobb, Sara and Rifkin, J. (1991), 'Practice and Paradox: Deconstructing Neutrality in Mediation' Law and Social Inquiry, 16: 35-62.

Cohn, B. (1959), 'Some Notes on Law and Change in North India', Economic Development and Cultural Change, 8(1): 79-93.

Concept on Strengthening EU Mediation and Dialogue Capacities, retrieved on June 3, 2013 at: http://register.consilium.europa. eu/pdf/en/09/st15/st15779.en09.pdf.

Cristescu, R., Nicolescou, A. and Wandi, A. (2012), ASEAN and Peace Mediation. Progress, Challenges, and Cooperation, Crisis Management Initiative Publication, retrieved on June 1, 2013 at: http://www.cmi.fi/images/stories/publications/ reports/2012/asean\%20report_web.pdf. 
Elgström, O., Bercovitch, J. and Skau, C. (2003), 'Regional Organisations and International Mediation: The Effectiveness of Insider Mediator', African Journal on Conflict Resolution, 3(1): 11-27.

Giessmann, H. J. and Wils. O. (2011), 'Seeking Compromise? Mediation Through the Eyes of Conflict Parties', in: Fischer, A. and Giessmann, H. J. (eds.). Advancing Conflict Transformation. The Berghof Handbook II. Budrich: pp. 183-206.

Golbert, R. (2009), 'An Anthropologist's Approach to Mediation', Cardozo Journal of Conflict Resolution, 11: 81-98.

Gourlay, C. and Ropers, N. (2012), 'Support for 'insider' mediators: A gap in EU ambitions for mediation?' in: Tamminen, Tanja (ed.), Strengthening the EU's peace mediation capacities. Leveraging for peace through new ideas and thinking, Report of the Finnish Institute of International Affairs.

Gurses, M., Rost, N. and McLeod, P. (2008), 'Mediating Civil War Settlements and the Duration of Peace', International Interactions, 34(2): 129-155.

Hislaire, P., Smith, R. and Wachira, G. (2011) 'Insider Mediators in Africa: Understanding and enhancing the contribution of Insider Mediators to the peaceful resolution of conflicts in Africa', PeaceNexus Foundation.

Jacobsen, E. and Liden, K. (2012), 'Theoretical Challenges for Assessing Socio-Cultural Sensitivity in Governance and Conflict Resolution', in: Galvanek, J., Giessmann,H. J. and Mubashir (eds.), Norms and Premises of Peace Governance. Socio-Cultural Commonalities and Differences in Europe and India, Berghof Occasional Paper, 32: 25-30.

Khadiagala, G. (2007), Meddlers or Mediators: African Interveners in Civil Conflicts in Eastern Africa, Leiden: Nijhoff.

Lee, J. and Hwee Hwee, Teh (eds.) (2009), An Asian Perspective on Mediation, Singapore: Academy Publishing.

Lund, M. (2001), 'A Toolbox For Responding To Conflicts and Building Peace', in: Reychler, L. and Paffenholz, T. (eds.), Peacebuilding, A Field Guide, Boulder: Lynne Rienner Publishers.

Mac Ginty, R. (2010), 'Hybrid Peace: The Interaction Between Top-Down and Bottom-Up Peace', Security Dialogue, 41(4): 391-412.

Mac Ginty, R. (2011), International Peacebuilding and Local Resistance: Hybrid Forms of Peace, Basingstoke: Palgrave Macmillan.

Mac Ginty, R., Pogodda, S., Richmond, O. and Vogel, B. (2012), 'Technocracy, Governance and Conflict Resolution', in: Galvanek, Giessmann, Mubashir (eds.), Norms and Premises of Peace Governance. Socio-Cultural Commonalities and Differences in Europe and India, Berghof Occasional Paper, 32: 37-43.

Mason, S. (2009), Insider mediators. Exploring their key role in informal peace processes, Berlin: Berghof Foundation for Peace Support.
Merry, S.E. (1987), 'Cultural frameworks of mediation', University of Hawai'I Program on Conflict resolution, Occasional Paper Series, No. 2.

Moore, Ch. (2003), The Mediation Process. Practical Strategies for Resolving Conflict. San Francisco: Jossey-Bass.

Paffenholz, T. (2001), Western Approaches to Mediation', in: Reychler, L. and Paffenholz, T. (eds.), Peacebuilding. A Field Guide, Boulder: Lynne Rienner.

Porter, E. and Every, D. (2009), 'Peacebuilding. Women peaceworkers', in: Bagshaw, D. and Porter, E. (eds), Mediation in the Asia-Pacific Region. Transforming Conflicts and Building Peace, Abingdon: Routledge.

Reich, H. (2006), 'Local Ownership in Conflict Transformation Projects: Partnership, Participation or Patronage?', Berghof Occasional Paper, 27.

Richmond, O. (2009), 'Eirenism and a Post-Liberal Peace', Review of International Studies, 35(3): 576-77.

Richmond, O. (2010), 'Resistance and the Post-liberal Peace', Millennium: Journal of International Studies 38(3):665-692.

Roberts, S. and Palmer, M. (2005), Dispute Processes: ADR and the Primary Forms of Decision-Making, Cambridge: Cambridge University Press.

Simmel, G. (1950), The Sociology of Georg Simmel, (compiled and translated by Kurt Wolff), Glencoe: Free Press.

Sisk, T. (2009), International Mediation in Civil Wars: Bargaining with Bullets, New York: Routledge.

Tamminen, T. (ed.) (2012), 'Strengthening the EU's peace mediation capacities. Leveraging for peace through new ideas and thinking', Report of the Finnish Institute of International Affairs.

UN Guidance for Effective Mediation (2012a), retrieved on June 2, 2013 at: http://peacemaker.un.org/sites/ peacemaker.un.org/files/GuidanceEffectiveMediation_ UNDPA2012\%28english\%29_1.pdf.

UN (2012b), General Assembly 66 session, Agenda item 34: Prevention of armed Conflict. Letter dated 9 May 2012 from the Permanent Representative of Turkey to the UN addressed to the Secretary-General, retrieved on June 9, 2013 at:

http://peacemaker.un.org/sites/peacemaker.un.org/ files/20120225_Summary\%20Report_\%20Istanbul\%20 Conference\%20on\%20Mediation.pdf.

Wehr, P. and Lederach, J.-P. (1991), Mediating Conflict in Central America', Journal of Peace Research, 28 (1): 85-98.

Wolff, S. and Yakinthou, C. (2011), Conflict Management in Divided Societies: Theories and Practice, London: Routledge.

Zartmann, I. W. and Touval, S. (1996), 'International Mediation in the Post-Cold War Era', in Crocker et al. (eds.), Managing Global Chaos, Washington, D.C.: United States Institute of Peace Press: 445-461. 